\title{
THE INCIDENCE OF ANTIBIOTIC RESISTANCE IN GRAM-NEGATIVE BACILLI IN A GENERAL HOSPITAL
}

\author{
BY \\ EDGAR F. THOMSON \\ From the Fairfax Institute of Pathology, Royal Prince Alfred Hospital, Sydney \\ (RECEIVED FOR PUBLICATION OCTOBER, 1951)
}

Five antibiotics-penicillin, streptomycin, aureomycin, chloromycetin, and terramycin - are now readily available for the treatment of diseases due to bacterial infection, and for the treatment of wounds infected either primarily or by hospital cross-infection. There is considerable overlapping in the selective activity of these antibiotics in that they are effective against Gram-positive bacteria in varying degree. The last four are also variably effective against the Gram-negative bacteria. There is, in addition, absolute selective activity in regard to some micro-organisms. Streptomycin alone is therapeutically effective against Myco. tuberculosis ; chloromycetin has a special selective action against the Rickettsiae; aureomycin and terramycin have a special selective action against the larger viruses. It is, therefore, important in every case to attempt to obtain a pure culture of the infecting organism, and to evaluate its sensitivity to the various antibiotics.

The widespread use of antibiotics has also produced the problem of antibiotic resistant organisms, a problem which is as important, in relation to the Gramnegative bacilli, as it is to the Gram-positive cocci, and it was felt that an analysis of the results of routine sensitivity tests over 12 months might yield significant information.

Bact. coli, $P$. vulgaris, Ps. pyocyanea, $H$. influenzae, and Bact. friedländeri were studied with regard to their sensitivity to streptomycin, aureomycin, chloromycetin, and terramycin.

The period under review is the 12 months from January 1, 1950, to December 31,1950 . From January 1,1950 , to June 30,1950 , streptomycin only was available. From July 1, 1950, onwards aureomycin, chloromycetin, and terramycin were gradually added to the battery of antibiotics, until, in the final period, October 1, 1950 , to December 31,1950 , all four antibiotics were used in the sensitivity tests.

The blood-agar plate medicated disc method of sensitivity testing has been used throughout. The method is simple and gives all the information that is required for control of antibiotic therapy. The antibiotics used in the tests were prepared in the following strengths.

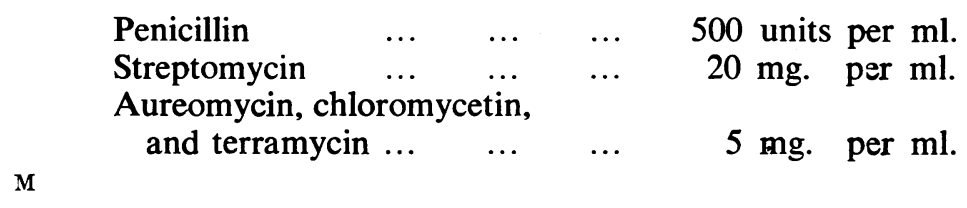


One drop of the antibiotic was placed on the paper disc. A control organism was cultured on each plate.

\section{Results}

Bact. coli.-Three hundred and twenty-four strains have been tested with streptomycin, 177 strains with aureomycin, 168 strains with chloromycetin, 137 strains with terramycin.

The 12-month period has been subdivided into (1) January 1 to June' 31,1950 ; (2) July 1 to September 30,1950 ; (3) October 1 to December 31, 1950. The results are shown in Table I.

TABLE I

Sensitivity to Streptomycin, Aureomycin, Chloromycetin, and Terramycin of Strains of Bact. coli

\begin{tabular}{|c|c|c|c|c|c|c|}
\hline \multirow{2}{*}{ Period of Isolation } & \multirow{2}{*}{ Antibiotic } & \multirow{2}{*}{$\begin{array}{c}\text { Total No. } \\
\text { of } \\
\text { Strains }\end{array}$} & \multicolumn{2}{|c|}{ Sensitive } & \multicolumn{2}{|c|}{ Resistant } \\
\hline & & & No. & $\%$ & No. & $\%$ \\
\hline January 1 to June 30,1950 & $\begin{array}{l}\text { Streptomycin } \\
\text { only }\end{array}$ & 115 & 61 & $53 \cdot 1$ & 54 & $46 \cdot 9$ \\
\hline July 1 to September 30,1950 & $\begin{array}{l}\text { Streptomycin } \\
\text { Aureomycin } \\
\text { Chloromycetin } \\
\text { Terramycin }\end{array}$ & $\begin{array}{l}87 \\
65 \\
56 \\
25\end{array}$ & $\begin{array}{l}45 \\
45 \\
45 \\
19\end{array}$ & $\begin{array}{l}51 \cdot 7 \\
69 \cdot 2 \\
80 \cdot 3 \\
76 \cdot 0\end{array}$ & $\begin{array}{r}42 \\
20 \\
11 \\
6\end{array}$ & $\begin{array}{l}48 \cdot 3 \\
30 \cdot 8 \\
19 \cdot 7 \\
24 \cdot 0\end{array}$ \\
\hline $\begin{array}{l}\text { October } 1 \text { to December } 31 \text {, } \\
1950\end{array}$ & $\begin{array}{l}\text { Streptomycin } \\
\text { Aureomycin } \\
\text { Chloromycetin } \\
\text { Terramycin }\end{array}$ & $\begin{array}{l}122 \\
112 \\
112 \\
112\end{array}$ & $\begin{array}{l}64 \\
43 \\
76 \\
73\end{array}$ & $\begin{array}{l}52 \cdot 4 \\
38 \cdot 3 \\
67 \cdot 0 \\
65 \cdot 0\end{array}$ & $\begin{array}{l}58 \\
69 \\
36 \\
39\end{array}$ & $\begin{array}{l}47 \cdot 6 \\
61 \cdot 7 \\
33 \cdot 0 \\
35 \cdot 0\end{array}$ \\
\hline July 1 to December 31,1950 & $\begin{array}{l}\text { Streptomycin } \\
\text { Aureomycin } \\
\text { Chloromycetin } \\
\text { Terramycin }\end{array}$ & $\begin{array}{l}209 \\
177 \\
168 \\
137\end{array}$ & $\begin{array}{r}109 \\
88 \\
121 \\
92\end{array}$ & $\begin{array}{l}52 \cdot 1 \\
49 \cdot 7 \\
72 \cdot 0 \\
67 \cdot 1\end{array}$ & $\begin{array}{r}100 \\
89 \\
47 \\
45\end{array}$ & $\begin{array}{l}47 \cdot 9 \\
50 \cdot 3 \\
28 \cdot 0 \\
32 \cdot 9\end{array}$ \\
\hline
\end{tabular}

The figures show that during these three periods the percentage of strains resistant to streptomycin has remained constant at $47-48 \%$. This stabilization might be expected, as streptomycin had been in free use within the hospital for at least 15 months before the beginning of the period under review. Observations made on Staph. pyogenes over the same periods of time (Rountree, Barbour, and Thomson, 1951, and unpublished data) have shown that the percentage of streptomycinresistant strains isolated in this hospital has now become stabilized around $25 \%$ to $30 \%$. Although there is no direct evidence, such as is available for Staph. pyogenes, that streptomycin-resistant strains of Bact. coli have arisen in, and are characteristic of, hospitals, it is not unreasonable to suppose that such is the case.

There has been an increase in aureomycin-resistant strains in the three months ending December, 1950 , from $30.8 \%$ to $61.7 \%$. This increase is statistically significant $\left(\chi^{2}=13.098 ; \mathrm{P}>0.01\right)$. A study of the values obtained in the next threemonth period should show whether this increase is of a permanent nature. A similar trend may be occurring in relation to chloromycetin-resistant and terramycin- 
resistant strains. This cannot, however, be established with any certainty until at least a further three-month period has been reviewed.

Another fact which emerges from the data is the high percentage of strains sensitive to chloromycetin $(72 \%)$ and to terramycin $(67.1 \%)$.

On analysing the figures for the period July to December, 1950, it was noted that 26 of 137 strains $(19.4 \%)$ were completely resistant to all four antibiotics.

P. vulgaris. - Two hundred and twenty-one strains have been tested with streptomycin, 77 with aureomycin and chloromycetin, and 72 with terramycin.

The 12-month period has been divided into (1) January 1 to June 30,1950 ; (2) July 1 to December 31,1950 . The results are shown in Table II.

TABLE II

Sensitivity to Streptomycin, Aureomycin, Chloromycetin, and Terramycin of STRAINS OF $\boldsymbol{P}$. vulgaris

\begin{tabular}{|c|c|c|c|c|c|c|}
\hline \multirow{2}{*}{ Period of Isolation } & \multirow{2}{*}{ Antibiotic } & \multirow{2}{*}{$\begin{array}{c}\text { Total No. } \\
\text { of } \\
\text { Strains }\end{array}$} & \multicolumn{2}{|c|}{ Sensitive } & \multicolumn{2}{|c|}{ Resistant } \\
\hline & & & No. & $\%$ & No. & $\%$ \\
\hline January 1 to June 30,1950 & $\begin{array}{l}\text { Streptomycin } \\
\text { only }\end{array}$ & 70 & 61 & $87 \cdot 1$ & 9 & $12 \cdot 9$ \\
\hline July 1 to December 31, 1950 & $\begin{array}{l}\text { Streptomycin } \\
\text { Aureomycin } \\
\text { Chloromycetin } \\
\text { Terramycin }\end{array}$ & $\begin{array}{r}151 \\
77 \\
77 \\
72\end{array}$ & $\begin{array}{r}113 \\
6 \\
49 \\
11\end{array}$ & $\begin{array}{r}74 \cdot 8 \\
7 \cdot 8 \\
63 \cdot 7 \\
15 \cdot 2\end{array}$ & $\begin{array}{l}38 \\
71 \\
28 \\
61\end{array}$ & $\begin{array}{l}25 \cdot 2 \\
92 \cdot 2 \\
36 \cdot 3 \\
84.8\end{array}$ \\
\hline
\end{tabular}

The increase in streptomycin-resistant strains from $12.9 \%$ to $25.2 \%$ over these periods is barely significant $\left(\chi^{2}=4.17 ; \mathrm{P}=0.15\right) ; 63.7 \%$ of the strains were sensitive to chloromycetin, while only $7.8 \%$ were sensitive to aureomycin, and $11 \%$ to terramycin. It is obvious that in the treatment of infections with $P$. vulgaris streptomycin and chloromycetin are the antibiotics of choice.

Ps. pyocyanea.-One hundred and thirty-one strains have been tested with streptomycin, 46 with aureomycin and chloromycetin, and 38 with terramycin.

The 12-month period has been divided into (1) January 1 to June 30, 1950 ; (2) July 1 to December 31,1950 . The results are shown in Table III.

TABLE III Sensitivity to Streptomycin, Aureomycin, Chloromycetin, and Terramycin of

\begin{tabular}{c|l|c|c|c|c|c}
\hline \multirow{2}{*}{ Period of Isolation } & Antibiotic & \multirow{2}{*}{$\begin{array}{c}\text { Total No. } \\
\text { of } \\
\text { Strains }\end{array}$} & \multicolumn{2}{|c|}{ Sensitive } & \multicolumn{2}{c}{ Resistant } \\
\cline { 3 - 7 } & & No. & $\%$ & No. & $\%$ \\
\hline January 1 to June 30,1950 & Streptomycin only & 68 & 34 & $50 \cdot 0$ & 34 & $50 \cdot 0$ \\
\hline July 1 to December 31, 1950 & Streptomycin & 63 & 26 & $41 \cdot 3$ & 37 & $58 \cdot 7$ \\
& Aureomycin & 46 & 3 & $6 \cdot 5$ & 43 & $93 \cdot 5$ \\
& Chloromycetin & 46 & 8 & $17 \cdot 4$ & 38 & $82 \cdot 6$ \\
& Terramycin & 38 & 18 & $47 \cdot 4$ & 20 & $52 \cdot 6$ \\
\hline
\end{tabular}


The incidence of streptomycin-resistant strains (50-58\%) has not altered significantly during the 12 months. The figures show clearly that this organism is very resistant to all antibiotic therapy, although response to terramycin may be expected in approximately $50 \%$ of cases. Aureomycin and chloromycetin would appear to be ineffective, since $80 \%$ to $90 \%$ of the strains tested were resistant to these substances.

Bact. friedländeri.-The figures shown in Table IV are for the whole period of 12 months. No percentages are given because the total number of strains investigated is too small. It should be noted, however, that the four strains investigated were all resistant to the action of terramycin, in contrast to the findings of Linsell and Fletcher (1950).

TABLE IV

Sensitivity to Streptomycin, Aureomycin, Chloromycetin, and Terramycin of STRAINS OF Bact. friedländeri

\begin{tabular}{c|l|c|c|c}
\hline Period of Isolation & Antibiotic & $\begin{array}{c}\text { Total No. } \\
\text { of } \\
\text { Strains }\end{array}$ & Sensitive & Resistant \\
\hline January 1 to December 31, 1950 & $\begin{array}{l}\text { Streptomycin } \\
\text { Aureomycin } \\
\text { Chloromycetin } \\
\text { Terramycin }\end{array}$ & 35 & 32 & 3 \\
& 4 & 3 & 1 \\
\hline
\end{tabular}

H. influenzae.-The figures shown in Table $\mathrm{V}$ are for the whole period of 12 months, and again, because of the small numbers of strains investigated, no percentages are expressed.

TABLE V

Sensitivity to Streptomycin, Aureomycin, Chloromycetin, and Terramycin of STRAINS OF $\boldsymbol{H}$. influenzae

\begin{tabular}{c|l|c|c|c}
\hline Period of Isolation & Antibiotic & $\begin{array}{c}\text { Total No. } \\
\text { of } \\
\text { Strains }\end{array}$ & Sensitive & Resistant \\
\hline January 1 to December 31, 1950 & Streptomycin & 19 & 19 & 0 \\
& Aureomycin & 3 & 2 & 1 \\
& Chloromycetin & 3 & 3 & 0 \\
& Terramycin & 3 & 3 & 0 \\
\hline
\end{tabular}

Streptomycin still appears to be the drug of choice for infections with $\boldsymbol{H}$. influenzae and Bact. friedländeri.

\section{Summary}

Five micro-organisms-Bact. coli, $P$. vulgaris, Ps. pyocyanea, $H$. influenzae, and Bact. friedländeri-have been tested for sensitivity to streptomycin, aureomycin, chloromycetin, and terramycin.

The percentages of sensitive and resistant strains isolated over the 12-month period, January 1, 1950, to December 31,1950 , are given. 
Three hundred and twenty-four strains of Bact. coli were examined. The percentage of strains resistant to streptomycin has remained constant over the period at $47 \%$ to $48 \%$. The percentage of strains resistant to aureomycin has increased from $30.8 \%$ to $61.7 \%$. The increase is statistically significant $\left(\chi^{2}=13.098\right.$; $P>0.01)$. A similar trend may be occurring in relation to the chloromycetin and terramycin.

Two hundred and twenty-one strains of $P$. vulgaris were tested with streptomycin ; 77 with aureomycin and chloromycetin, 72 with terramycin. There has been an increase in the streptomycin-resistant strains from $12.9 \%$ to $25.2 \%$ over the period. This is barely statistically significant $\left(\chi^{2}=4.17 ; \mathrm{P}>0.15\right)$. Of the strains tested with chloromycetin, $63.7 \%$ were sensitive. Streptomycin and chloromycetin are the antibiotics of choice in infections with $P$. vulgaris.

One hundred and thirty-one strains of Ps. pyocyanea have been tested with streptomycin ; 46 with aureomycin and chloromycetin, 38 with terramycin. This organism is very resistant to all antibiotic therapy, but response to terramycin and streptomycin may be expected in approximately $50 \%$ of cases.

A small series of results with Bact. friedländeri and $H$. influenzae is shown. The four strains of Bact. friedländeri tested were all resistant to terramycin. Streptomycin still appears to be the antibiotic of choice for infections with these two organisms.

I should like to thank Dr. Phyllis Rountree for her valuable help and criticism, and Mr. George Barr and Miss Vera Sife for their technical assistance.

REFERENCES

Linsell, W. D., and Fletcher, A. P. (1950). Brit. med. J., 2, 1190.

Rountree, P. M., Barbour, R. G. H., and Thomson, E. F. (1951). Lancet, 1, 435.

\section{AD D E N D U M}

Since this paper was written further tests have been carried out in the period January 1, 1951, to March 31, 1951, and the results are shown in Tables VI, VII, and VIII. During this period 514 strains of Bact. coli, 160 strains of P. vulgaris, and 83 strains of Ps. pyocyanea were tested. When the results are compared with those for the period July 1, 1950, to December 31, 1950, it will be seen that the

TABLE VI

Sensitivity to Streptomycin, Aureomycin, Chloromycetin, and Terramycin of STRAINS OF Bact. coli

\begin{tabular}{|c|c|c|c|c|c|c|}
\hline \multirow{2}{*}{ Period of Isolation } & \multirow{2}{*}{ Antibiotic } & \multirow{2}{*}{$\begin{array}{c}\text { Total No. } \\
\text { of } \\
\text { Strains }\end{array}$} & \multicolumn{2}{|c|}{ Sensitive } & \multicolumn{2}{|c|}{ Resistant } \\
\hline & & & No. & $\%$ & No. & $\%$ \\
\hline January 1 to March 31,1951 & $\begin{array}{l}\text { Streptomycin } \\
\text { Aureomycin } \\
\text { Chloromycetin } \\
\text { Terramycin }\end{array}$ & $\begin{array}{l}514 \\
514 \\
514 \\
514\end{array}$ & $\begin{array}{l}248 \\
166 \\
300 \\
319\end{array}$ & $\begin{array}{l}48 \cdot 2 \\
32 \cdot 2 \\
58 \cdot 4 \\
62 \cdot 2\end{array}$ & $\begin{array}{l}266 \\
348 \\
214 \\
195\end{array}$ & $\begin{array}{l}51 \cdot 8 \\
67 \cdot 8 \\
41 \cdot 6 \\
37 \cdot 8\end{array}$ \\
\hline
\end{tabular}


TABLE VII

Sensitivity to Streptomycin, Aureomycin, Chloromycetin, and Terramycin of STRAINS OF $\boldsymbol{P}$. vulgaris

\begin{tabular}{c|c|c|c|c|c|c}
\hline \multirow{2}{*}{ Period of Isolation } & Antibiotic & $\begin{array}{c}\text { Total No. } \\
\text { of } \\
\text { Strains }\end{array}$ & \multicolumn{2}{|c|}{ Sensitive } & \multicolumn{2}{|c}{ Resistant } \\
\hline January 1 to March 31, 1951 & Streptomycin & 160 & 108 & $\%$ & No. & $\%$ \\
& Aureomycin & 160 & 20 & $12 \cdot 5$ & 140 & $87 \cdot 5$ \\
& Chloromycetin & 160 & 101 & $63 \cdot 1$ & 59 & $36 \cdot 9$ \\
& Terramycin & 160 & 21 & $13 \cdot 1$ & 139 & $86 \cdot 9$ \\
\hline
\end{tabular}

TABLE VIII

Sensitivity to Streptomycin, Aureomycin, Chloromycetin and Terramycin of STRAINs OF Ps. pyocyanea

\begin{tabular}{|c|c|c|c|c|c|c|}
\hline \multirow{2}{*}{ Period of Isolation } & \multirow{2}{*}{ Antibiotic } & \multirow{2}{*}{\begin{tabular}{|} 
Total No. \\
of \\
Strains
\end{tabular}} & \multicolumn{2}{|c|}{ Sensitive } & \multicolumn{2}{|c|}{ Resistant } \\
\hline & & & No. & $\%$ & No. & $\%$ \\
\hline January 1 to March 31,1951 & $\begin{array}{l}\text { Streptomycin } \\
\text { Aureomycin } \\
\text { Chloromycetin } \\
\text { Terramycin }\end{array}$ & $\begin{array}{l}83 \\
83 \\
83 \\
83\end{array}$ & $\begin{array}{r}39 \\
6 \\
14 \\
24\end{array}$ & $\begin{array}{r}47 \cdot 0 \\
7 \cdot 2 \\
16 \cdot 9 \\
29 \cdot 0\end{array}$ & $\begin{array}{l}44 \\
77 \\
69 \\
59\end{array}$ & $\begin{array}{l}53 \cdot 0 \\
92 \cdot 8 \\
83 \cdot 1 \\
71 \cdot 0\end{array}$ \\
\hline
\end{tabular}

trend is towards an increase in resistant strains, e.g. the strains of Bact. coli resistant to aureomycin have risen from $50.3 \%$ to $67.8 \%$; those resistant to chloromycetin have increased from $28.0 \%$ to $41.6 \%$; the strains of Ps. pyocyanea resistant to terramycin have increased from $52.6 \%$ to $71.0 \%$. 